\title{
THE MIDDLE ENGLISH MYRROUR OF SYMPLE SOULES: MORE THAN A "RHETORIC" OF DEIFICATION?
}

\author{
Louise Nelstrop*
}

\begin{abstract}
This essay argues that the glosses in the late-fourteenth, early fifteenth-century Middle English work pe Myrrour of Symple Soules are more theologically coherent than has previously been posited. Focusing on the discussion of "usages" that they contain, as well as the importance of freedom, a case is made for reading many of the annotations to be advocating a Thomist/Bonaventurean account of deification, that is, suggesting that the soul loves God through a created habitus that allows the Holy Spirit to work in the soul without obliterating it. Although a more theologically conservative understanding of deification than usually posited of the original Mirouer, it nonetheless indicates that the translator may have offered his readers more than a "rhetoric of ecstasy," demonstrating concern that they understand what it means to be deified in union with God.
\end{abstract}

Keywords: Marguerite Porete, Bonaventure, Thomas Aquinas, deification, habitus, Medieval Theology.

\section{INTRODUCTION}

The late fourteenth-early fifteenth Middle English work pe Myrrour of Symple Soules was rediscovered during a wave of interest in the esoteric and mystical at the beginning of the twentieth century. ${ }^{1}$ In 1911, J.A. Herbert, the Keeper of Manuscripts in the British Museum, brought it to the attention of Evelyn Underhill, in what is now BL MS Addition 37790 (the Amherst manuscript). ${ }^{2}$ Another early twentieth-century female scholar, Hope Emily Allen, subsequently discovered pe Myrrour extant in two further manuscripts (MS Bodley 505 and St John's College, Cambridge MS 71) along with Richard Methely's Latin translation of the Middle English (in Pembroke College,

\footnotetext{
* Margaret Beaufort Institute of Theology, 12 Grange Road, Cambridge, CB3 9DU/St Benet's Hall, 38 St. Giles Oxford, OX1 3LN/Ruusbroec Institute, S.GK. 32-34, Prinsstraat 13, 2000, Antwerpen, louise.nelstrop@theology.ox.ac.uk. I am extremely grateful to John Arblaster, David Jasper and the anonymous reviewers for their helpful comments, all remaining errors are my own. This article was completed with the help of an UCSIA scholarship at the Ruusbroec Institute at the invitation of Veerle Fraeters.

${ }^{1}$ Marguerite Porete, The Mirror of Simple Souls trans. Clare Kirchberger (London 1927) intro xxi. The critical edition of the Middle English is: Marguerite Porete, The Mirror of Simple Souls: a Middle English Translation, ed. Marilyn Doiron (Rome 1968) [pe Myrrour]. For the critical edition of the Latin: Margaretae Porete, Speculum simplicium animarum, Corpus Christianorum Continuatio Mediaevalis 69, ed. Paul Verdeyen (Turnholt 1986) [Speculum]. For the critical edition of the French: Marguerite Porete, "Il Miroir des simples âmes di Margherita Porete," ed. Romano Guarneri, Archivio Italiano per la Storia della Pietà 4 (1965) 501-708 [Miroir]. The English text will be referred to as pe Myrrour and Marguerite's lost original as the Mirouer. On the dating of pe Myrrour: Robert F. Stauffer, "M.N. and the Yorkshire Circle: The Motivation Behind the Translation of the Mirouer des Simples Ames in Fourteenth-Century England" (Unpublished PhD diss., Arizona State University 2011) 132-139.

${ }^{2}$ Kirchberger (n.1 above) xxi.
} 
Cambridge, MS 221). ${ }^{3}$ Based on its intellectual and theological content, Underhill held it a great work of mysticism, one that she announced recounted the deification of the human soul:

The history of human transcendence is the history of the soul's transmutation to that condition of love in which it is, as the author [of pe Myrrour] is not afraid to say, deified; and so merged in the Reality from which it came forth, that it is no longer aware of its own separate experience but is "all one spirit with its Spouse."

Underhill does not unpack exactly what she means by deification here, but it is clear from an earlier essay that she viewed pe Myrrour to postulate daring doctrines that she aligned closely with a Dionysian school of thought. ${ }^{5}$ She suggests that the translator does not however, share the original author's spiritual proclivities, advocating instead a more theologically conservative understanding of mysticism closer to that found in the writings of Walter Hilton. ${ }^{6}$ The controlling effect of the translator's annotations have led subsequent scholars to diminish further the sense in which pe Myrrour offered its readers access to the idea of deification. The aim of this study is to revisit the claim that be Myrrour, complete with its glosses, promotes deification. Although I agree with Nicholas Watson, Marlene Cré and Underhill that in many ways that translator's interpretation is conservative, i.e., not propagating an understanding of deification as radical as we find in the writings of William of St. Thierry and Meister Eckhart, I hope to show that the translator-known only by his or her initials M.N.-offers readers a much more nuanced and complex theological engagement with deification than the "rhetoric of ecstasy" that Watson has proposed, ${ }^{7}$ advancing instead an understanding of deification close to that espoused by Thomas Aquinas and Bonaventure. I will begin by briefly situating this study of pe Myrrour in the scholarly literature.

When the pe Myrrour was first rediscovered, the author was unknown. However, in 1946, based on her study of a Latin Vatican MS, Rossianus 4, Romana Guarnieri attributed the text to a woman, Marguerite Porete, who was

\footnotetext{
${ }^{3}$ Richard Methley, Speculum Animarum Simplicium: A glossed Latin version of "The Mirror of Simple Souls, ” ed. John Clark, Analecta Carthusiana 266 (2010). Justine L. Trombley notes the catalogue entry for Pembroke MS 221 wrongly states a fragment of Methley's text is found in Latin Laud 46; this fragment is from the Latin Mirror: "The Latin Manuscripts of The Mirror of Simple Souls," in Companion to Marguerite Porete and The Mirror of Simple Souls, eds. Wendy R. Terry and Robert F. Stauffer (Leiden 2017) 186-217 at 188, n. 5.

${ }^{4}$ Evelyn Underhill, The Essentials of Mysticism and Other Essays (London 1920) 143.

${ }^{5}$ Evelyn Underhill, "The Mirror of Simple Souls," Fortnightly Review 95 (1911) 345-54.

${ }^{6}$ Ibid. 346.

${ }^{7}$ Nicholas Watson, "'Melting into God the English Way': Deification in the Middle English Version of Marguerite Porete's Mirour des simples âmes anienties," in The Reception of Continental Holy Women in Late Medieval England, ed. Rosalyn Voaden (Cambridge 1996) 1950; Marlene Cré, Vernacular Mysticism in the Charterhouse: A Study of London, British Library, MS Additional 37790 (Turnhout 2006).
} 
burned alive in la Place de Grève in Paris in 1310 as a relapsed heretic. ${ }^{8}$ Knowing that the text was originally written in French but assumed lost, Guarnieri subsequently identified the Middle French manuscript (Chantilly Musée Condé MS F xiv 26) as a French version of Marguerite's work. We know very little about Marguerite, except what can be gleaned from her trial notes. ${ }^{9}$ Scholars have postulated various reasons for Marguerite's condemnation. It has been suggested, for example, that the text is antinomian, and contains a radical notion of deification. ${ }^{10}$ A number of scholars hold the latter to be one likely factor contributing to Marguerite's fate. ${ }^{11}$ Barbara Newman, for example, argues that, "Marguerite's abjection is, in an ontological sense, absolute. As an annihilated soul, 'she' no longer exists. Yet by the same token, she is God ... Abjection and exaltation ... coalesce in a Zenlike tranquillity that orthodox mystics ... would judge to be dangerous self-delusion." 12

Given Marguerite's fate, it is surprising that the text survives - most complete copies are late and none are in Picard, the language in which the work was most probably composed. ${ }^{13}$ Scholars dispute which of the surviving versions comes

\footnotetext{
${ }^{8}$ On Guarneri's attribution and subsequent evidence in its favor: Sean L. Field, Robert E. Lerner and Sylvian Piron, "A Return to the Evidence for Marguerite Porete's authorship of the Mirror of Simple Souls,” Journal of Medieval History 43.2 (2017) 153-173.

${ }^{9}$ Marguerite subsequently described as a "beguine" (a lay religious woman) and "pseudomulier." On these attributions: Michael G. Sargent, "Marguerite Porete," in Medieval Holy Women in the Christian Tradition c.1100-c.1500, eds Alastair Minnis and Rosalyn Voaden (Turnhout 2010), 291-303 at 292, ns. 2-4. On Marguerite's trial: Sean L. Field, The Beguine, the Angel, and the Inquisitor: the Trials of Marguerite Porete and Guiard of Cressonessart (Notre Dame 2012). On beguines: Tanya Stabler Miller, The Beguines of Medieval Paris: Gender, Patronage, and Spiritual Authority (Philadelphia 2014).

${ }^{10}$ For a discussion and counterargument: John Arblaster and Rob Faesen, "“Commune à tous par largesse de pure charité': Common Love in Beatrice of Nazareth and Marguerite Porete," Ons Geestlijk Erf, 84.4 (2012) 297-323. Robert E. Lerner initially proposed Porete a key proponent of the Free Spirit Heresy: The Heresy of the Free Spirit in the Later Middle Ages (Los Angeles 1976) 71 but subsequently modifies this position: idem, "New Light on 'The Mirror of Simple Souls'," Speculum, 85.1 (2010) 91-116.

11 Juan Marin, "Annihilation and Deification in Beguine Theology and Marguerite Porete's Mirror of Simple Souls," Harvard Theological Review, 103:1 (2010) 89-109; Margeret Porette, The Mirror of Simple Souls, foreword Kent Emery, trans. Edmund Colledge, Jack C. Marler and Judith Grant, Notre Dame Texts in Medieval Culture 6 (Notre Dame 1999). Robert E. Lerner, "The Image of Mixed Liquids in Late Medieval Thought," Church History 40 (1971) 397-411.

${ }^{12}$ Barbara Newman, From Virile Woman to WomanChrist: Studies in Medieval Religion and Literature (Philadelphia 1995) 164. For a defence of Porete's account of deification: Arblaster and Faesen, "Commune' (n. 10 above). Michael G. Sargent argues that the text is orthodox, although incautiously written: "'Le Mirouer des simple âmes' and the English Mystical Tradition," in Abendländische Mystik im Mittlealter: Symposino Kloster Engelberg 1984, ed. Kurt Ruh (Stuttgart 1986) 423-465.

${ }^{13}$ Excluding Methley's translation of the Middle English, the work is extant in seven Latin manuscripts (one recently discovered), in Middle French, extant in one manuscript (noted above), in early Italian, extant in five manuscripts, containing two different Italian translations. There is also a short extract in Picard, in what is known as the Picard Fragment. The surviving Latin MSS are: Vatican City, Biblioteca apolstolica vaticana, Vat. Lat, 4355, Rossianus 4, Chigianus B IV 14, Chigianus C IV 15, Vat lat 3953, and Oxford Bodleian Library, Laud Latin 46. On Trombley's recent discovery: "New Frontiers in the Late Medieval Reception of a Heretical Text: The
} 
closest to the lost original. ${ }^{14}$ pe Myrrour is set apart by a series of annotations, inserted by M.N., at strategic points. ${ }^{15}$ M.N. has not been definitively identified. In a recent essay, Robert Stauffer argues that the best candidate is neither Michael Northgate (more properly Northburgh) nor his son (both of whom have been posited as possible) but a woman, Matilde Newton, who was briefly the first abbess of the newly founded Brigittine House in London, Syon Abbey. ${ }^{16}$ Although this is an attractive reading, the attribution is far from certain given that the text seems to have circulated in Carthusian circles. ${ }^{17}$ Since Denis

Implications of Two New Latin Copies of Marguerite Porete's Mirror of Simple Souls," in Late Medieval Heresy: New Perspectives: Essays in Honor of Robert E. Lerner, ed., Michael D. Bailey and Sean L. Field (York 2018) 157-177. The title given in the Middle French Chantilly manuscript is le mirouer des simples âmes anéanties et qui seulement demeurent en vouloir et désir d'amour. However, Louisa Muraro rejects this on the ground that Marguerite's annihilated souls have no will: "Le mirouer des simples ames de Marguerite porete: Les avatars d'un titre," Ons geestelijk erf 70 (1996) 3-9. On the English and French MSS: Michael G. Sargent, "Medieval and Modern Readership of Marguerite Porete's Mirouer des simples ames anienties: The French and English Traditions," in Middle English Religious Writing in Practice: Texts, Readers, and Transformations, ed. Nicole R. Rice (Turnhout 2013) 47-89. On the Italian MSS: Dávid Falvay, "The Italian Version of The Mirror: Manuscripts, Diffusion and Communities in the $14^{\text {th }}$ and $15^{\text {th }}$ Centuries," in Companion, ed. Terry and Stauffer (n. 3 above) 218-239; idem., "Medieval and Modern Readership of Marguerite Porete's Mirouer des simples âmes anienties: The Manuscripts of the continental Latin and Italian Traditions," in In principio fuit interpres: The Medieval Translator/Traduire au Moyen Âge 15, ed. Alessandra Petrina (Turnhout 2013) 85-96. On all the manuscripts: Geneviève Hasenohr, "The Tradition of the Mirror of Simple Souls in the Fifteenth Century: From Marguerite Porete (d. 1310) to Marguerite of Navarre," trans. Zan Kocher, in Companion, ed. Terry and Stauffer (n. 3 above) 155-185; Marlene Cré, "Further Thoughts on M.N.'s Middle English Translation of Marguerite's Mirouer des simples ames anienties," in Companion, edited by Terry and Stauffer (n. 3 above) 240-263 and Trombley, "The Latin Manuscripts" (n. 3 above).

${ }^{14}$ Verdeyen's critical edition of Mirrouer was re-constructed using all language versions except the Picard Fragment, which was discovered later. For a scholarly overview: Sean L. Field, Robert E. Lerner and Sylvain Piron, eds., Marguerite Porete et le Miroir des simples âmes: perspectives historiques, philosophiques et littéraires (Paris 2013), and Companion, ed. Terry and Stauffer (n. 3 above). On how the Picard Fragment complicates this: Hasenohr, "Tradition" (n. 13 above); Jonathan Juilfs, "Mirrors on the Wall: Which One Is Fairest of Them All?" in Companion, ed. Terry and Stauffer (n. 3 above) 323-338. For the priority of the Middle English: Lerner, "New Light" (n. 10 above).

${ }^{15}$ Marilyn Doiron was to the first to discuss the Middle English text. In addition to the fifteen glosses, she comments on a number of omissions: "The Middle English Translation of The Mirouer of Simples Ames," in L. Reypens and Albert Ampe, Dr L. Reypens-Album (Antwerp 1964) 131152. Methley removes the glosses in his Latin translation but inserts his own - around 100 in total.

${ }^{16}$ Lerner, "New Light" (n. 10 above) maps a possible relationship between Northburgh (he corrects the attribution 'Northgate') and Valenciennes. Most scholars agree the most likely candidate is Michael Northburgh or Michael Free aka Northburgh (possibly the former's illegitimate son). However, Robert F. Stauffer, "Possibilities for the Identity of the English Translator of the Mirror of Simple Souls," in Companion, ed. Terry and Stauffer (n. 3 above) 264 289 at 265, n. 8 .

17 On circulation of Marguerite's text in France: Zan Kocher, "The Apothecary's Mirror of Simple Souls: Circulation and Reception of Marguerite Porete's Book in Fifteenth-Century France," Modern Philology, 111.1 (2013) 23-47. On circulation of Middle English translations of continental texts: Michael G. Sargent, "The Transmission by the English Carthusians of some Late Medieval Spiritual Writing," Journal of Ecclesiastical History 27 (1976) 225-240. In 
Renevey has argued that, regardless of gender, M.N.'s voice is masculine, and as I am arguing that M.N. interjects a scholastic understanding of deification, to avoid clumsy constructions such as $\mathrm{s} / \mathrm{he}$, for the rest of this essay I will refer to M.N. using the male pronoun. ${ }^{18}$

In total, pe Myrrour contains fifteen glosses, enclosed by the first and last letters of the translator's name. ${ }^{19}$ M.N. tells the reader that he has translated the work out of French, that it contains many hard sayings, and that this is a second revised attempt to clarify parts that were obscure/problematic - the Middle English "hap be mystake" ${ }^{20}$ can mean either. M.N. states that he has, in a few places, put in more than the text contains, bracketing these glosses with his initials. ${ }^{21}$ Yet the exact purpose of the glosses remain unclear. Edmund Colledge and Romana Guarnieri suggested that M.N. was quite possibly aware of a now lost list of propositions taken from the Mirouer and used to condemn it. ${ }^{22}$ However, Watson, Cré and Michael G. Sargent and have all shown that the latter reading is not entirely convincing. ${ }^{23}$ Watson stresses how unlikely it is that the author, who does not show much concern that his readers misunderstood his first translation, would try to knowingly salvage a condemned work through annotation. He instead posits that, lacking understanding of the daring spiritual ideas of union that were circulating on the continent, M.N. was not a "strong reader" of the text, particularly where continental ideas of deification are concerned. ${ }^{24}$ Sargent largely concurs. Taking each gloss in turn, and noting how

tentative support of a female translator: Cré, "Further Thoughts," (n. 13 above) 251; idem, "The Mirror of Simples Souls in Middle English Revisited: The translator and the compiler," in Marguerite Porete, eds. Field, Lerner and Piron (n. 14 above), 249-262.

${ }^{18}$ Denis Renevey, "Le Pouvoir de la Voix Masculine: Le Case de la Version en Moyen-Anglais du Mirror des Simples Âmes de Marguerite Porete," in Body Politics; Discours Corporels \& Corps Discursifs, Special Edition of Études de Lettres: Revue de la Faculté de l'Université de Lausanne 258, eds., Lucy Perry, Kirsten Stirling and Boris Vejdovsky (2001) 33-54.

${ }^{19}$ Colledge and Guarnieri count only 14 glosses plus the prologue (Edmund Colledge and Romana Guarnieri, "The glosses by M. N. and Richard Methley to "The Mirror of Simple Souls," in The mirror ed., Doiron (n. 1 above), Appendix, 357-382 at 371. However, Sargent notes that this miscount results from not commenting on annotation 12: "the English Mystical Tradition," (n. 12 above) 457.

${ }^{20}$ pe Myrrour (n. 1 above) 247.8 .

${ }^{21}$ Ibid. 248.25-30. See: Sargent, "the English Mystical Tradition," (n. 12 above) 446.

${ }^{22}$ Colledge and Guarnieri, "The glosses" (n. 19 above) 358.

${ }^{23}$ Watson finds little to link M.N.'s annotations to the Heresy of the Free Spirit: "Melting" (n. 7 above); Cré, Vernacular Mysticism (n. 7 above) 180; Sargent, "the English Mystical Tradition" (n. 12 above); Idem, "The Annihilation of Marguerite Porete," Viator 28 (1997) 253 - 79.

${ }^{24}$ Watson, "Melting" (n. 7 above) 37. Watson appears to assume that radical ideas of deification were unknown in England. However, Peter Lombard's Sentences and William of St. Thierry's Golden Epistle were widely known; both contain a radical understanding of deification: On the circulation of William's texts in England: Shape, Catalogues, http://mlgb3.bodleian.ox.ac.uk/authortitle/results/?search type=advanced\&go button start=Go\& text $=\& \mathrm{t}$ author $=$ William\&t title $=\& \mathrm{t}$ bibliography $=\& \mathrm{t}$ library $=\& \mathrm{t}$ document $=\&$ s document ty $\mathrm{pe}=\& \mathrm{q}$ earliest year $=\& \mathrm{q}$ latest year $=\&$ order by $=$ solr id sort\&start $=500 \quad$ On William's probably influence on Marguerite, see Arblaster, n. 76 below. Roger Lovatt also notes that John Blacman gifted a copy of De Adhaerendo Deo to the Carthusian abbey in Witham: "The Library 
few can be linked to statements found in Marguerite's condemnation, Sargent views it as a defence of orthodoxy in terms of M.N.'s "uninspired repetition of the argument that the author is speaking only of the transitory experience of rapture." 25

Watson does not however, abandon the possibility that M.N. is speaking of deification. He posits that M.N's glosses push towards an understanding of deification which he considers most clearly exemplified in the writings of Richard Rolle. Watson suggests that Rolle's mysticism culminates in Melos Amoris in a rhetorical outpouring - "an esoteric rhetorical fantasy"- that replaces his earlier experiential enthusiasm, manifest in three experiences - heat, sweetness and song (canor) ${ }^{26}$ As Watson puts it in his monograph on Rolle,

[...] we have apparently reach a position [in Melos Amoris] in which either canor is no longer treated as the highest stage of the spiritual life at all, or else is thought of as consisting, in its highest form, in its own proclamation to the world - in which case Rolle must have thought of the actual text of Melos Amoris as not metaphorically but literally a form of mystical experience, a form superior to the ineffable ecstasy he once regarded as canor. ${ }^{27}$

In similar vein, he suggests that pe Myrrour offers its reader "the rhetoric of ecstasy," claiming that while deification for Bernard of Clairvaux culminates in silence, that of M.N., like Rolle's, terminates in a new form of speech. Watson argues that while this means that pe Myrrour is not part of an insular "backwater" from which the idea of deification is entirely absent, it nonetheless belongs to an Englishing of deification that strips it of its radical force by reducing it to the level of an affective speech-act. As he puts it:

Like Rolle and the Monk of Farne, M.N. is deeply interested not in the complex theology surrounding the ineffable experience of mystical union, but in the rhetoric of ecstasy, in the ability of words to convey the feelings which accompany elevated states of soul, and, on a more theoretical level, on the subjective component of all religious language when it is used in an affective context. ${ }^{28}$

of John Blacman and Contemporary Carthusian Spirituality," Journal of Ecclesiastical History 43.2 (1992) $195-230$ at 230 .

25 Sargent, "the English Mystical Tradition," (n. 12 above) 460.

${ }^{26}$ Nicholas Watson, Richard Rolle and the Invention of Authority, (Cambridge, 1991), 189.

${ }^{27}$ Watson, Richard Rolle and the Invention of Authority, 181-2.

28 Watson, "Melting" (n. 7 above) 46. For a different reading of the Monk of Farne on deification: Louise Nelstrop, "The Monk of Farne: A Forgotten Medieval English Mystic," in Mystical Doctrines of Deification: Case Studies in the Christian Tradition, eds., John Arblaster and Rob Faesen (London 2018) 135-151. It seems worth noting that Watson does not seem to have in mind what might be termed a "rhetoric of ecstasy" in the Pseudo-Dionysian corpus, in which Paul Rorem has cogently argued that ecstasy entails "standing outside ourselves and our natural affirmative use of language about God": Pseudo-Dionysius: A Commentary on the Texts and an Introduction to their Influence (New York 1993), 186. Although connected to experience of liturgy and sacrament, it is devoid of experience of feelings connected to love: Rorem, PseudoDionysius, 191, 224; idem, Biblical and Liturgical Symbols within the Pseudo-Dionysian Synthesis (Toronto 1984), 137. Later authors, such as Thomas Gallus (although not Eckhart who was most 
The likelihood of this reading is, for Watson, bolstered by the prevalence of sweetness terminology in M.N. annotations, language also marked in the writings of Rolle and another insular author, John Howden. Yet, the model of deification that Watson propounds lacks an antecedent - indeed he argues that Rolle invents his own authority based on experiences. Understandings of Rolle's account of deification more congruent with prior Christian accounts have subsequently been posited. ${ }^{29}$ It is also worth noting that sweetness discourse is ubiquitous in medieval mystical writing and does not necessarily indicate M.N.'s debt to Rolle or other English writers, ${ }^{30}$

This does not, however mean that M.N. does not offer a conservative reading. Cré notes that a number of the glosses narrow the playfulness of the French, thereby simplifying and diverting attention away from the complex doctrinal problems that dog the Mirouer. ${ }^{31}$ However, she finds no overarching theological strategy behind this and therefore concludes that M.N. reads the text as "a concatenation of 'usages' or elevated spiritual experiences." ${ }^{32}$ This leads her to agree with Watson that M.N. offers his readers a "rhetoric of ecstasy," albeit one that, through his translation, provides his readers access to the Mirouer:

M.N. ... does not mine the text for its theological doctrines, which he shows little interest in, but he presents it to his readers as a rich testimony of the unknown author's experience of union with God. ${ }^{33}$

I hope to show that M.N.'s glosses do not necessarily limit the reader in this way. Building on Cré's observation concerning the importance of "usages," in what follows, I suggest that a more theologically coherent understanding of M.N.'s glosses is possible; one that advances the idea of deification beyond mere rhetoric, although doing so more conservatively than Marguerite may have intended.

likely was influenced by Porete), interpreted Dionysius' Mystical Theology in a more affective experiential manner but in so doing obfuscated the rhetorical dimension of ecstasy: Rorem, Pseudo-Dionysius, 222; Denys Turner, The Darkness of God: Negativity in Christian Mysticism (Cambridge 1995) esp. 193.

${ }^{29}$ For an alternative reading of Rolle's understanding of deification: Richard Rolle, Richard Rolle's Melody of Love: A Study and Translation with Manuscript and Musical Contexts trans and intro Andrew Albin (Toronto 2018), 102-103; Louise Nelstrop, On Deification and Sacred Eloquence: Richard Rolle and Julian of Norwich (Abingdon 2020).

30 Mary Carruthers, "Sweetness," Speculum 81.4 (2006) 999-1013. Laurie A. Finke subsequently supported a position closer to Colledge and Guarnieri suggesting that the glosses, "no doubt were intended as, a heavy-handed reassertion of monologic authority designed to 'correct' a flawed reading and save it for orthodoxy": "More Than I Fynde Wirtten,' Dialogue and Power in the English Translation of The Mirror of Simple Souls," in Performance and Transformation: New Approaches to Late Medieval Spirituality, eds., Mary A. Suydam and Joanne E. Ziegler (London, 1999) 47-67 at 63.

${ }^{31}$ Cré, Vernacular Mysticism (n. 7 above) 180-197.

${ }^{32}$ Ibid. 189.

${ }^{33}$ Ibid 190, 196. 
II FREEDOM AND DEIFICATION IN AQUINAS AND BONAVENTURE The text of pe Myrrour is considerably shorter than its French or Latin counterparts. ${ }^{34}$ It lacks part of chapter 122, all of chapters $123-125$, and part of 126 as well as chapters $137-139 .{ }^{35}$ This means that the English text draws to a close soon after a discussion of God's bounty or goodness, and a description of the seven states through which the righteous or free soul passes. Here, in section 13, we learn about the nature of the soul and of free souls whose wills never consent to $\sin .^{36}$ It is here too that we find M.N.s final annotation, one of two annotations added, after M.N. states that he has glossed all those passages that "haue be mystake." 37

The final gloss is short and appears obscure. It occurs just after a lengthy discussion of how the soul is made up of two aspects - the spirit and the body. ${ }^{38}$ The first, we are told, is "made of God," the latter is "fourmed of God," the two natures being conjoined to form one constitution. ${ }^{39}$ Yet there is corruption and failings occur. The bold claim is then made that free souls do not need correction since such is only required when one sins with consent and free souls do not consent to their failings. Failings result instead from the corruption of the flesh which belongs only to their bodies. Quoting Proverbs 24.16 "the righteous man falleth seven times a day," pe Myrrour maintains that free souls are therefore blameless even when the flesh fails; such a soul could no more sin than could God, otherwise the virtuous behaviour that God instills within it would harm it. ${ }^{40}$ Given the radical nature of the passage, a fairly lengthy quotation seems justified:

Oo, seip pis soule ... now I haue sum of pat pat hooli writ seip, pat pe ri3tful fallip seuene tymes a day. He is wel yclered pat vndirstandip pat pis is not in cause of correccion, for correccion is whanne men fallen in defaute of consentynge of her wille, and corrupcion is pe fleschilinesse of pe conplexion of oure bodies. It semep ellis bi pis tale pat I haue not fre wille, if I moste synne azens my wille seuene tymes a day. It is not so wip Goddis grace, seip pis soule, for it moste be pat God is not God if uertues be binome me, mawgre me. For no more pan God may synne pat may not wille it, no more may I synne if my wille wole it not, such fredom hap pe summe of me of his pure bounte bi loue y3ouen me. ${ }^{41}$

\footnotetext{
${ }^{34}$ Ibid. $192-193$.

${ }^{35}$ On this: Ibid. 260; Cré, "Further Thoughts" (n. 13 above).

${ }^{36}$ pe Myrrour (n. 1 above) 326-330, esp. 328.18 - 330.23 (chapters 103-105 of the Latin text).

${ }^{37}$ Ibid. 304.26 - 305.31. The two additional glosses appear at 313.27-314.17 and 329.1113.

${ }^{38}$ Ibid. $328.21-329.10$.

${ }^{39}$ Ibid. 328. 21-22.

${ }^{40}$ Ibid. $329.8-10$.

${ }^{41}$ Ibid. 329.1-10 [Kirchberger (n.1 above) 224] Kirchberger finds the beginning of this passage especially obscure (223).
} 
The implication of this passage, at least at first glance, seems to be that no matter what the body does, the soul is pure because free. All faults committed lie with the body and the corruption inherent in human sensuality. It could be taken as justification for libertinism. ${ }^{42}$ One might expect some gloss on these claims, yet M.N. simply comments on the second half of the final sentence, writing:

Pe summe of pis soule is pe knowing pat sche hap of pe goodnesse of God, and pis goodnesse of God pat is pe Hooli Goost werkip in her pat zaue hir free wille. ${ }^{43}$

This gloss has drawn little scholarly interest since, as Colledge and Guarnieri comment, where one would expect a discussion of the difficult idea that free souls may be permitted to sin in their bodies without being held responsible, M.N. concentrates on providing what seems to be a rather mundane explanation of the word "summe." 44 Given that the word "summe" is found neither in the French nor Latin text, Sargent suggests M.N. was perhaps "unsatisfied with the nonsense reading" he found in the text. ${ }^{45}$ Colledge and Guarnieri wonder if M.N. misunderstood the Mirouer here, or whether he perhaps hunted around for a passage with which to distract his readers from the text's radical claims. ${ }^{46}$ However, the annotation might not be as banal as has been supposed.

At the heart of pe Myrrour's discussion of the will of the free soul quoted above, we find a reference to Proverbs 24.16 "the righteous man falleth seven times a day." ${ }^{, 47}$ In the Latin and French the idea that this verse relates to the correction of the soul is dismissed as only useful for the donkeys who don't understand the Mirouer. ${ }^{48}$ Although this statement is not replicated in the Middle English, the verse is nonetheless taken to mean that the corruption of the flesh results in a failing for which the free soul doesn't need correction. pe Myrrour itself clarifies a little later on that scripture is not wrong to describe this failing as a fall since faults occur as a consequence of the frailty of Adam's body. The failing is credited to the soul as a virtue since it provides an opportunity for the soul to demonstrate the surety of its will, which lives free: "is more uertu to him pat vice bicause of pe wille pat dwellip fre bi refusynge pe defaute." ${ }^{.49}$ Given worries over the orthodoxy of Marguerite's text, perhaps easily overlooked is an $23]$.

${ }^{42}$ M.N., however, specifically denys this in annotation 4 [pe Myrrour (n. 1 above) 259.20-

${ }^{43}$ pe Myrrour (n. 1 above) 329.11-12. [Kirchberger (n.1 above) 225.3-7].

${ }^{44}$ Colledge and Guarnieri, "The glosses" (n. 19 above) $371-2$.

45 Sargent, "the English Mystical Tradition," (n. 12 above) 459.

${ }^{46}$ Colledge and Guarnieri, "The glosses" (n. 19 above) 371. Also: Katherine Kerby-Fulton, Books Under Suspicion: Censorship and Tolerance of Revelatory Writing in Late Medieval England (Notre Dame 2006) 285, who argues against a too insular reading of English spirituality, 280.

${ }^{47}$ pe Myrrour (n. 1 above) 329.2.

${ }^{48}$ Mirouer (n. 1 above) 280-283.

${ }^{49}$ pe Myrrour (n. 1 above) 330.3-13. [Kirchberger (n.1 above) 226-227.19] On the place of the will in the text of the Mirrouer: Danielle C. Dubois, "The Virtuous Fall: Marguerite Porete, Meister Eckhart and the Medieval Ethics of Sin," Journal of Religious Ethics 3.3 (2015) 432-453. 
underlying concern over spiritual freedom. The second passage extends the first, in which the anxious soul worries it will have no free will if the biblical passage means that the soul must will to sin seven times a day: "It semep ellis bi pis tale pat I haue not fre wille." It affirms that it is God's goodness that guarantees the freedom of the soul and it is on God's Goodness - God's bounty - that M.N. comments. ${ }^{50}$ Cré notes M.N.'s glosses are "interpretative rather than corrective" in two ways. Firstly M.N. builds them from material found elsewhere in the text of pe Myrrour and secondly he reads the texts "within the framework of texts that were considered orthodox." ${ }^{, 1}$ Although not mentioning any sources by name, Aquinas' response to and rejection of Peter Lombard's identification of the charity that operates within the soul as the Holy Spirit responds to similar concerns over spiritual freedom in ways that possibly shed light on M.N.s final glosses as well as a number earlier annotations. Aquinas discusses this idea in his Quaestio disputata de caritate, Commentary on the Sentences (Scriptum super libros Sententiarum Magistri Petri Lombardi), his recently discovered Roman Lectures on the Sentences and Summa Theologiae. ${ }^{52}$ In what follows I suggest that thinking on deification in line with that advocated by Aquinas and Bonaventure in his Sentence Commentary and his Breviloquium likely influenced M.N. in his composition of a number of the glosses. ${ }^{53}$

Peter Lombard's Sentences had, by the thirteenth-century, become a standard university textbook on which all candidates for degrees in theology had to lecture. Many went on, around the age of 33, to produce commentaries on Lombard's Sentences sometimes in conjunction with works of Aristotle. ${ }^{54}$ One topic that became a particular source of debate was Sentences, I d.17, with Aquinas even remarking in his Roman Lecture, I d.17 c. 2 that the Lombard was mistaken. ${ }^{55}$ Here we find the Lombard claiming that: "the Holy Spirit is the love of the Father and the Son by which they love each other and us. It must be added to this that the very same Holy Spirit is the love or charity by which we love God

\footnotetext{
${ }^{50}$ pe Myrrour (n. 1 above) 330.7-8.

${ }^{51}$ Cré, Vernacular Mysticism (n. 7 above) 184.

${ }^{52}$ Geetjan Zuijdwegt, "'Utrum caritas sit aliquid creatur in anima:' Aquinas on the Lombard's identification of charity with the Holy Spirit," Recherches de Théologie et Philosophie médiévales 79.1 (2012) 39-74, notes that Aquinas discusses this issue in Quaestio disputata de caritate, in Quaestiones disputatae, $9^{\text {th }}$ revised edition, ed. P. Bazzi et al, vol. 2 (Turin-Rome 1953); Scriptum super libros Sententiarum Magistri Petri Lombardi, ed. R.P. Mandonnet, vol 1 (Paris 1929) I, d. 17, q. 1, a. 1; Lectura romana in primum Sententiarum Petri Lombardi, ed. L.E. Boyle and J.F. Boyle, Studies and Texts 125 (Turnhout 2006) I, d. 17, q. 1, a. 2; Summa Theologiae, Opera Omnia, Leonine edition, vol. 8 (Rome 1895) http://www.corpusthomisticum.org/repedleo.html (IIa-IIae, q. 23, a. 2).

${ }^{53}$ For discussion of the circulation of these work in England in the later Middle Ages see ns. 111 and 112 below.

${ }^{54}$ See: Steven J. Livesey "Lombardus electronicus: A Biographical Database of Medieval Commentators on Peter Lombard's Sentences," in Mediaeval Commentaries on the Sentences of Peter Lombard: Current Research, ed. Gillian R. Evans (Leiden 2001) vol. 1, 1-23 and Russell L. Friedman, "The Sentences Commentary, 1250-1320. General Trends, The Impact of Religious Orders, and the Test Case of Predestination," in idem, 41-128.

${ }^{55}$ See Zuijdwegt, "Aquinas," (n. 52 above) 51.
} 
and neighbour." ${ }^{56}$ The idea that the Holy Spirit is not only the love that flows between the members of the Trinity and humans but also the very love through which the soul loves God is, as Philipp Rosemann has argued, "theological dynamite. ${ }^{, 57}$ Crucially for Aquinas, as Zuijdwegt points out, it suggests that the soul's love for God is not free. ${ }^{58}$ I will focus particularly on Quaestio disputata de caritate and the Scriptum super libros Sententiarum Magistri Petri Lombardi where Zuijdwegt notes that the argument is most detailed. ${ }^{59}$

In Quaestio disputata de caritate 1.a., Thomas begins by stressing that just as motion is voluntary only if it is not the result of some external force, so too in order for the motion of the will to be voluntary, its operation must result from something internal rather than external. If the soul loved God through the charity that is the Holy Spirit, such love would not be freely given by the soul. Even if it could be somehow claimed that love caused by an external force could be a true act of the will, Aquinas argues that the soul would remain unchanged in the act of loving, and so would accrue no merit. It would be like a puppet, or as Aquinas puts it: "Therefore if the soul does not effect an act of charity through some proper form, but only because it is moved by an extrinsic agent, i.e., by the Holy Spirit, then it will follow that it is considered only as an instrument for this act." ${ }^{60}$ Such a soul would experience no joy or delight in love, since love is the source of all merit and all goodness. Aquinas argues that this cannot be the case. Emphatically rejecting the Lombard's position, Aquinas argues that the Holy Spirit operates in the soul as a created habit, which allows the soul to accrue merit since the Holy Spirit would be supplying the soul with a supernatural but created virtue, which would give the soul itself the power to will the good over and above its fallen natural capacities, which cannot do this as a consequence of

${ }^{56}$ Peter Lombard, The Sentences, trans. Giulio Silano (Toronto 2007-2010), 4 vols., vol 1. 88. "[...] omnes catholici concedunt, scilicet quod Spiritus Sanctus sit caritas Patris et Filii; quod autem ipse idem sit caritas qua diligimus Deum et proximum, a plerisque negatur," Peter Lombard, Sententiae in IV libris distinctae, ed. I. M. Brady (Grottaferrata 1971-81), vol 1, I, d. 17, c. 6.1, $148-149$.

${ }^{57}$ P.W. Roseman, "Fraterna dilectio est Deus: Peter Lombard's Thesis on Charity as the Holy Spirit," in Amor amicitiae: On the Love that is Friendship: Essays in Medieval Thought and Beyond in Honor of the Rev. Professor James McEvoy," eds., T.A.F. Kelly and P.W. Roseman (Peeters 2004), 409- 436 at 410, quoted in Zuijdwegt, "Aquinas," (n. 52 above) 40.

${ }^{58}$ This issue is the focus of Zuijdwegt's study: "Aquinas," (n. 52 above).

${ }^{59}$ Zuijdwegt notes that Aquinas's most detailed response is found in his Quaestio disputata de caritate a.1, although he also deals with the issue in similar terms in Summa Theologiae IIa-IIae, q. 23, a. 2, as well as in his earlier Scriptum super libros Sententiarum Magistri Petri Lombardi.

${ }^{60}$ Aquinas, On Charity, trans. Lottie H. Kenkzierski (Milwaukee 1984) 22 [in The Collected Works of Thomas Aquinas, Electronic Edition (Charlottesville, Virginia, USA: InteLex Corporation)]. "si anima non agit actum caritatis per aliquam formam propriam, sed solum secundum quod est mota ab exteriori agente, scilicet Spiritu sancto, sequetur quod ad hunc actum se habeat sicut instrumentum tantum," Quaestio disputata de caritate, a. 1, resp., 755. 
the Fall. ${ }^{61}$ As he states: "there must be a certain habit of charity created in us, which is the formal principle of the act of love." 62

It is precisely this point that Zuijdwegt also sees Thomas making in his earlier Commentary on the Sentences. In I, d. 17, q. 1, a. 1, sol. Using 1 Cor. 13 ("if I ...have not charity, I am nothing" v2), Thomas stresses that the soul's entire goodness is from charity, without which it would be nothing. Exploring how goodness comes about, and using the example of civic life, Aquinas argues that political or civic life is shaped by virtues that are acquired and make the one who possesses them and his work good. In a similar way, charity perfects the soul and so must operate within the soul through a created habitus (habitus creatus). His reasoning is as follows: The form of being good cannot be understood apart from the grace and charity that infuses the soul. The power of being good is dependent on that power having been perfected by a habit. ${ }^{63}$ As Zuijdwegt puts it: "The supernatural virtue of charity changes the created subject in two ways, first, it offers a new way of being (forma) and secondly, it offers a new power of acting (habitus). Because it supernaturally changes the created subject in this way, it is itself created." ${ }^{64}$ In Aquinas' model it is clear that the soul shares in the love of God but it does so through its own internal capacity - albeit a supernatural capacity that is infused within the soul-it retains its created status even in this act of love. For Aquinas "charity is a created habitual form in the soul of the believer, which enables the free and full participation of human beings in the divine love." ${ }^{65}$ Since this is a created supernatural capacity it does not overwhelm the nature of the soul. It rather provides the platform for the Holy Spirit to work continually within it.

So long as it is understood that the Holy Spirit works through a created habitus, Aquinas is happy to affirm that the Holy Spirit is indeed operational within the soul. Such a habitus would allow the soul to participate in the love of God but would not jeopardize free will because it would constitute an internal operation of the soul and, whilst allowing the soul ongoing participation in God by means of grace, would not entail a once and for all identification of the soul and God. In this respect, Thomas differentiates between created and uncreated charity: "the Holy Spirit, Who is Uncreated Charity, exists in man who has created charity, or that He moves man's soul to the act of love, as God moves all things to their own actions to which they are inclined by their own proper forms." ${ }^{\prime \prime 6}$ This, however does not entail a rejection of the idea of deification. For

\footnotetext{
${ }^{61}$ Zuijdwegt, "Aquinas,” (n. 52 above) 65.

62 Aquinas, On Charity (n. 60 above) 22. "oporteat esse quemdam habitum caritatis in nobis creatum, qui sit formale principium actus dilectionis," Quaestio disputata de caritate, a. 1, resp., 755:

${ }^{63}$ Zuijdwegt, "Aquinas,” (n. 52 above) 60.

${ }^{64}$ Ibid.

${ }^{65}$ Ibid 67.

${ }^{66}$ Aquinas, On Charity (n. 60 above) 22 "Nec [...] excluditur quin Spiritus sanctus, qui est caritas increata, sit in homine caritatem creatam habente, movens animam ad actum dilectionis, sicut Deus movet omnia ad suas actiones, ad quas tamen inclinantur ex propriis formis," Quaestio disputata de caritate, a. 1, resp., 755.
} 
Aquinas, deification is defined as an act of participation, as it is in the writings of the Early Church Fathers, rather than as an act of obliteration-a possible reading of the Lombard's position. ${ }^{67}$ Aquinas supports deification so long as this is understood to mean that the soul retains its created integrity and freedom and results from the operation of grace. As Zuijdwegt summarizes,

Deification, however, is beyond our capacities. Hence, God graces us with the created yet supernatural habitual form of divine love, which allows us to perform acts of charity freely, meritoriously, readily and with delight. That, according to Aquinas, is how God orders all things sweetly. ${ }^{68}$

Although there were competing readings of the Lombard's position in this period-Richard Fishacre postulated that sharing in the love of the Trinity entailed some kind of "(quasi)hypostatic union," a position against which Thomas also reacts ${ }^{69}$ - Bonaventure's understanding, as outlined in his Commentary on the Sentences and in his Breviloquium, appears close to that of Thomas. Likewise responding to the portrayal of deification that he finds in Peter Lombard's Sentences I.17.q.1, Bonaventure argues that the Lombard's position is defective if he is claiming that we love God and neighbor through the love that is the Holy Spirit in itself. This, Bonaventure stresses, would have a number of heretical implications, including the obliteration of the soul in union with God or conversely Pelagianism, because it could imply that through our natural tendencies we are able to attain perfection. In order to avoid these, Bonaventure similarly argues that it is necessary to insist that the charity which is in the soul, through which the soul loves God, is a created habit (caritatem habitum creatam) ${ }^{70}$ It is this which gives the soul the capacity to conform itself to the will of God whilst in no way diminishing God. In his Breviloquium Bonaventure again argues that the Holy Spirit is instrumental in creating a habitus or disposition within the soul, through which the soul is made receptive to the Holy Spirit, who then comes to dwell within the soul as in a temple. Bonaventure states here that this indwelling makes the soul deiform: ${ }^{71}$

${ }^{67}$ Zuijdwegt, "Aquinas," (n. 52 above) 70-72. On Aquinas and deification: Luke Davis Townsend, "Deification in Aquinas: A Supplementum to The Ground of Union," Journal of Theological Studies N.S. 66.1 (2015) 204 -234; On deification in the Early Church Fathers: Norman Russell, The Doctrine of Deification in the Greek Patristic Tradition (Oxford 2004).

${ }^{68}$ Zuijdwegt, "Aquinas," (n. 52 above) 74.

${ }^{69}$ Ibid. 56-59. For a discussion of Fishacre's commentary: R. James Long, "The Beginning of a Tradition: The Sentences Commentary of Richard Fishacre OP," in Commentaries, ed. Evans (n. 54 above) $345-357$.

${ }^{70}$ Bonaventure, "Commentaria in Quatuor Libros Sententiarum Mastri Petri Lombardi," Opera Omnia (Quaracchi) ad clarus aquas, tomum 1 (propre florentiam, 1882-1885) I. 17.q. 1. r 3. 295.

${ }^{71}$ In his article, "Divinisation: B. Théologiens du $13^{\mathrm{e}}$ siècle," Dictionnaire de Spiritualité (Paris 1954), Humbert-Thomas Conus notes Bonaventure use of the term deiformis is somewhat ambiguous. At times, it refers to nothing more than a natural attribute, i.e., the soul's divine origin and its inherent capacity to reflect God due to its being created in God's image and likeness. Yet 
If then, the rational spirit is to become worthy of eternal happiness, it must partake of this God-conforming influence. This influence that renders the soul dei-form [deiformis] comes from God, conforms us to God, and leads to God as our end. ${ }^{72}$

However, Bonaventure explains that this does not lead to a confusion between the soul and God - the soul receives an influence that emanates from God and is conformed to God in terms of its disposition or habitus:

Not that God comes down in the terms of the immutable divine essence, but rather through an influence that emanates from God. Neither is the soul lifted up in a physical sense, but by virtue of a habit that renders it conformed to God. ${ }^{73}$

In suggesting this Bonaventure, like Aquinas, draws a distinction between created grace (habitus) and uncreated grace (the Holy Spirit) which allows him to argue that the deiform soul never possesses the essence of God but only God's effects ${ }^{74}$ as such he affirms that this does not impinge on the soul's free will. ${ }^{75}$ The position which both Bonaventure and Aquinas counter is very close to that which, according to Arblaster, shapes the understanding of deification in the Mirouer itself. ${ }^{76}$ However, it is not clear that this view shapes pe Myrrour when read in the light of a number of M.N.'s annotations. He seems to suggest that the text advocates a position far closer to that of Aquinas and Bonaventure.

If we return to the passage in pe Myrrour with which we began this section, we noted that the text is concerned with how spiritual freedom can be maintained. The text asks how God can be God if the virtues God has instilled cause harm ("for it moste be pat God is not God if uertues be binome me, mawgre me"). The text explores whether the soul is helpless in the face of sin ("It semep ellis bi pis tale pat I haue not fre wille, if I moste synne azens my wille seuene

Bonaventure also uses it to convey a sense in which the soul is transformed and made divine through a union with God that arises out from the operation of uncreated grace.

${ }^{72}$ Bonaventure, Breviloquium, trans. D. V Monte (New York 2005), V.1.3. "Necesse est igitur spiritui rationali, ut dignus fiat aeternae beatitudinis, quod particeps fiat influentiae deiformis. Haec autem influentia deiformis, quia est a Deo et secundum Deum et propter Deum, ideo reddit imaginem nostrae mentis conformem beatissimae," Bonaventure, "Breviloquium, "Opera Omnia, tomum 5 (n. 70 above) $252 \mathrm{~b}$.

${ }^{73}$ Bonaventure, Breviloquium (n. 72 above) V.1.3. "Deus autem non condescendit per sui essentiam incommutabilem, sed per influentiam ab ipso manantem; nec spiritus elevator supra se per situm locale, sed per habitum deiformem" (n. 72 above).

${ }^{74}$ Bonaventure thus speaks of a "divinely infused" adoption, Breviloquium (n. 72 above) V.1.5.

75 Bonaventure, Breviloquium (n. 72 above) V.1.4. "Rursus, quoniam qui fruitur Deo Deum habet; ideo cum gratia, quae sua deiformitate disponit ad Dei fruitionem, datur donum increatum, quod est Spirtus sanctus, quod qui habet habet et Deum" (n. 72 above).

${ }^{76}$ John Arblaster, "The Pious Jackal and the Pseudo-Woman: Doctrines of Deification in Medieval France," in Mysticism in the French Tradition: Eruptions from France, eds. Louise Nelstrop and Bradley B. Onishi (Farnham, 2015), 121-48 at 134. For discussion of the influence of William of St. Thierry on later female mystics and also Peter Lombard: John Arblaster, "On Becoming 'not God but what God is:' Essays on the Doctrine of Deification in the Late Medieval Low Countries" (Unpublished PhD diss., KU Leuven 2016). 
tymes a day"). It stresses that the soul is free because God, through goodness and love, has given the soul the capacity for freedom ("such fredom hap pe summe of me of his pure bounte bi loue y3ouen me"). M.N.'s focus on the word 'summe' draws attention to the soul's all, its essence, and how that relates to the freedom that God has given her. Although the gloss here is far too short for us to draw firm conclusions about M.N.'s position in relation to freedom and deification, as I will illustrate, several of M.N's glosses appear self-consistent. We find a number of comments that show similar concerns, thereby reinforcing one another.

III DEIFICATION IN DE MYRROUR: MERELY A "RHETORIC OF ECSTASY"? M.N.'s initial gloss relates specifically to the idea of spiritual freedom, and in it he himself introduces Proverbs 24.16: on failing seven times a day. ${ }^{77}$ Here he, not the text, tells the reader that the righteous spirit or will does not consent to sin and that this continues to be the case even after the moment of union or ecstasy has passed. Retaining a similar division between body and spirit to that advocated in the passages surrounding his final annotation, M.N. asserts that grace is at work within perfect souls enabling the godly will to retain a perfect and continuous connection to God's will:

But whanne a soule is drawe into hirsilf from al outward ping, so pat loue werip in pe soule - bi whiche pe soule is for a tyme departid fro al synne and is vnyed to God bi vnyoun - panne is pe soule fre. As for pat tyme of vnyoun, ful litel tyme it is. And whanne sche comep doun perfro, panne is sche pralle, fallynge or fadinge. To pis acordep hooli writ, where pat it seip: Sepies in die cadit iustus. But pis fallinge of pe riztwise is more merit pan synne, bicause of pe goode wille pat stondith vnbroken, and is vnyed to God. A creature may be enhabited bi grace in fredom foreuere; but to stonde contynuelli in freedom wipoute synne, it may not, for be vnstabilite of pe sensualite pat is alwei flittinge. And perfore it is arettid pe fallynge to pe sensualitie, $\&$ not to pe hooli soules pat parfiitli haue sett her wille in God, bi whiche loue makep hem fre for be noblie of his werk. Perefore it may wel be seid: not we lordis fre of al, but loue of him for us. ${ }^{78}$

Sargent draws attention to the fleeting nature of union stressed here by M.N. ${ }^{79}$ Yet what is also striking is the suggestion that the soul is made free when it is eternally inhabited by grace. As M.N. states here, "A creature may be enhabited bi grace in fredom foreuere." Although M.N. does not spell out what he means by such inhabitation, the reference follows immediately after the claim that the soul is free because its good will retains an unbroken union with God (a state that is contrasted with its own human disposition to sin). Directly after the reference to inhabitation we find the statement that its natural sinfulness prevents

\footnotetext{
${ }^{77}$ pe Myrrour (n. 1 above) 251.22-252.4 (251.29). 4.21].

${ }^{78}$ pe Myrrour (n. 1 above) 251.24-252.4 (my emphasis). [Kirchberger (n.1 above) 3.24-

${ }^{79}$ Sargent, "the English Mystical Tradition," (n. 12 above) 447, an issue that he notes stressed elsewhere by M.N. (451).
} 
it from remaining in continual freedom, but those that perfectly "sett her wille" in God can through this love be free to carry out the nobility of God's work and remain free. Indeed, it seems it is only sensuality that experiences fleeting union. It seems clear from the annotation that M.N. claims that the soul is free to set her will in God, despite the ability to do so being a gift from God. Thus M.N. introduces the idea of inhabitation precisely at the point of discussing what it means for the soul to be free to love God - stressing that such freedom is bound up with grace's eternal inhabitation.

That M.N. has in mind the kind of thinking on habitus that is espoused by Aquinas and Bonaventure is reinforced in annotation seven, where following a brief discussion of good works, M.N. again mentions the idea, stressing that it is God who inhabits the soul:

God is enhabited in hem and werkep in hem, and pese soules suffern him werke his diuine werkis in hem. ${ }^{80}$

Here we are told that God inhabits certain souls and works within them and that it is they that allow God to work his divine work in them; again a sense of spiritual freedom is stressed. He goes on to state that the work is nonetheless totally from God and "al in Goddis goodnesse"-an idea we find echoed elsewhere in pe Myrrour itself. For example, in the chapter that directly follows annotation 11 pe Myrrour describes how the goodness of the soul is linked to the indwelling of the Holy Spirit. The soul is said to be taken up into the Trinity and given a treasure that is enclosed within the Trinity and we are told that she has this not by divine nature but by strength of love and "pat pe Trinite in her enhabite." ${ }^{81}$ Thus M.N. is not simply imposing the idea of inhabitation on the text; his annotations are interpreting an already existing idea. Read together with such passages, annotations one and seven infer that M.N. holds that even though God inhabits the soul by grace, and that this is entirely God's work, this nonetheless enables the soul herself to freely will. Although the language that relates to this idea in pe Myrrour and M.N.'s annotations is more ambiguous than that of Bonaventure or Aquinas - by inhabitation M.N. could simply mean that God dwells within the soul without a created habitus - further glosses suggest that M.N. does indeed have something akin to a habitus in mind. This emerges as M.N. connects the ideas of inhabitation, spiritual freedom and virtue.

We see this, for example, in his fourth annotation, where M.N. explains that although free souls let go of virtues, they continue to perform them out of habit "as bi usage of good custom." ${ }^{82}$ At the same time, the free soul does not attend to these usages, instead all her attention is taken up with the "usages of loue, pe whiche ben alle diuine and upward." 83 These latter we are told are God's own

\footnotetext{
${ }^{80}$ pe Myrrour (n. 1 above) 262.6 - 7. [Kirchberger (n.1 above) 30.28-31.2].

${ }^{81}$ Ibid. 288.15-18; 26-27. [Kirchberger (n. 1 above) 104.10-19; $105.4-7$ ].

${ }^{82}$ Ibid. $258.16-259.30(259.3-4)$.

${ }^{83}$ Ibid. $259.6-7$.
} 
work wrought by love and are internal. Here customary usages are contrasted with "diuine usages": "bi usage of good custom pis soule doip pese outward werkis. But sche doip it wipoute desire and wipoute manner of usage pat she hadde bifore, in laborynge bi forayn willes. But fulli sche attendip in al pat sche may to be usages of loue, pe whiche ben all diuine and upward." ${ }^{84}$ Such "divine usages" could be extraordinary experiences as Cré suggests. The connection made with ordinary habits, however, suggests that M.N. has divine habits in mind. The word "usage" in Middle English is most often used to mean practice, custom, habit or disposition. "Divine usages" appear to be those which the soul only receives after she has perfected the ordinary virtues: "Pei desire for Goddis sake dispite, pouert, tribulacion ...for bi pis wey and bi sharp contricion, soules moste go, er pan pei come to pese diuine usages." or dispositions that allow the soul to taste "pe swete drawtes of heuenli fluences. ${ }^{87}$ Such usages are contrasted to "usage of good custom" by which the soul "doip pese outward werkis." Once the soul is infused with divine usages we see a shift in her attention-her focus now is no longer on perfecting ordinary virtues but in loving through supernatural love, "pe usages of loue, pe whiche ben alle diuine and upward." It is this way, M.N. argues, that the soul is "so vnyed to loue, pat it is loue pat doip it, and pus sche suffrip loue to werke in hir." ${ }^{88}$ From the fourth annotation it seems that M.N. is suggesting that the key to loving God lies with the divine usage or habits that have been instilled in the free soul-they are not the result of the soul's effort, for they work in her, yet they also do not occur unless she has prepared her soul for them. They similarly do not work apart from her, rather they enable the righteous soul to be free to love - they are internal to the soul although divine.

In his eleventh gloss M.N. comments on a passage that discusses the soul sharing in the life of the Trinity. The passage itself ends rather obliquely with Colledge and Guarneri not unreasonably suggesting that the Middle English is corrupt here: "I haue noon opir vsage, ne noon opir usage may haue, so me on comep pis knowinge in continence." ${ }^{\prime 9}$ The reference to "continence" makes little sense. Yet it is this passage that M.N. sees fit to annotate, glossing in particular the term "usage". He comments on how usages come and go, and that these are the ordinary dispositions that inhabit the soul customarily:

Takep kepe of pese wordis pat pe soule seip, pat sche hap noon opir usage ne noon opir may haue. bat is to seie, as for be tyme of pat usage, for rizt so euery usage

\footnotetext{
${ }^{84}$ Ibid. 259.3 - 7. [Kirchberger (n.1 above) 23.3-10].

85 Middle English Dictionary online: https://quod.lib.umich.edu/cgi $/ \mathrm{m} / \mathrm{mec} / \mathrm{med}-$ $\underline{i d x}$ ?size $=$ First $+100 \&$ type $=$ headword\&q1 $=$ usage $\& \operatorname{rgxp}=$ constrained $($ accessed $25 / 05 / 18)$.

${ }^{86}$ pe Myrrour (n. 1 above) 258.21, 23-24.

${ }^{87}$ Ibid. 258.25.

${ }^{88}$ Ibid. $259.7-8$. The whole passage runs from lines $258.21,23-26$ to $259.2-8$ [Kirchberger (n.1 above) $21.19-22.1 ; 23.1-12]$.

${ }^{89}$ Ibid. 282.34 - 35. Kirchberger (n.1 above) modifies "continence" into "continually": "I have none other usage nor none other usage may have, so overcometh me this knowledge continually.", [88.17-19].
} 
stondep for pe tyme of his werk, not pat the soule is contynuelli beynge in hem, for pat may not be, but every usage is had oon aftir anopir, as loue werkip \& as disposicions comen and good, but pese usages ben enhabited in pe soule and used in custom. Perefore it is sed in such termes as "alwei." Pus in pis wise many such opir wordis in pis booke moste be take..$^{90}$

Colledge and Guarneri have little to say about M.N.'s discussion of 'usages'. "Usage" is a term that we find throughout the text of the Mirouer. Colledge and Guarneri suggest that its meaning is obscure, referring to Marguerite's 'many mysterious allusions to the Soul's "usages." "91 Yet regardless of what Marguerite may have meant by this term, in this annotation M.N. compares customary usages with the usages or habits that the soul receives in her vision of the Trinity with the implication that just because the Trinity gives the soul a certain disposition, this does not mean that the soul lets go of all other usages or good habits. This reading is reinforced by other annotations in which ordinary habits and supernatural or divine habits are likewise contrasted, with the latter connected to the love through which the soul loves God.

In annotation two, for instance, M.N. tells us that when the soul tastes deeply of love, it is the love of God who works within the soul and has his usage or habit in her: "And whanne pe soule hap deepli taasted of pis loue, so pat pis loue of God werkip and hap his vsages in pe soule, panne pe soule is wondir lizt \& gladsome. ${ }^{.92}$ It is this that gives her mastery over the virtues, not any kind of antinomianism. As M.N. continues, "Panne is sche mastresse and lady ouer pe uertues, for sche hap them alle wipynne hirsilf, redy at hir comaundement, wipouten bittirnesse or peynfulnesse to felinge of pe soule." ${ }^{93}$ Here M.N. explicitly stresses the internal nature of the soul's divine usages and that she is not puppet. When read in the light of the other annotations a clear sense emerges that God has created a disposition within the soul through which it loves God and it is in this context that the Holy Spirit works in such souls, holding his "school" within them and arraying them with the flowers of his high nobility. ${ }^{94}$ Such ideas also appear in the tenth annotation where M.N. refers to divine usages as those that lead to "pure love" 95 and in the thirteenth gloss where M.N. argues that difficult passages in the Mirouer relate to "pese heuenli usages of Goddes werk," which exceed ordinary human capacities. ${ }^{96}$ Although the soul sometime fails to engage with ordinary virtues, we are told that these are times when it is

${ }^{90}$ Ibid. 283.1 - 7. I have slightly amended this quotation in line with a suggestion from the anonymous reviewer. [Kirchberger (n.1 above) 88.20 - 22 - 89.11] Kirchberger states that "usage" should be understood to mean 'devotional practice' in this passage, $88, \mathrm{n}$. 2, although as noted below it can equally be translated as virtue or habit.

${ }^{91}$ Colledge and Guarnieri, "The glosses" (n. 19 above) 367.

92 pe Myrrour (n. 1 above) 255.27-29. [Kirchberger (n.1 above) 14.3-7] Kirchberger suggests that usages here should be translated as "his habitual working" [14, n. 1].

${ }^{93}$ Ibid. 255.30 - 32. [Kirchberger (n.1 above) 14.11-15].

${ }^{94}$ Ibid. $259.27-28$.

95 Ibid. 279.9.

${ }^{96}$ Ibid. 305.2 - 3. "these heavenly usages of God's work" [Kirchberger (n.1 above) 151.19]. 
preoccupied with God's habits or usages ("pese restful usages of pure loue" ${ }^{97}$ ). It is the latter which enable God to work in the soul and plant his seed within her. As M.N. writes: "Stynte ze sumtume and beholdep God ... \& thanne he wole sowe his diuine seedis in $30 u, " 98$ an image that could also imply inhabitation.

Whilst pe Myrrour does not contain an explicit discussion of created and uncreated grace, we do find ideas in the text pertaining to this. Immediately after M.N's final annotation, we find a discussion of divine goodness or bounty, which we are told has conveyed bounty to the soul giving it free will: "But his bounte may not suffre him pat his powere vnfre me of fre wille in no wise. Pis is pat no powere binome me my wille if my wille wole not assente perto. Now hap his bounte bi pure bounte fre wille bi bounte $30 v e n$ me." find a lengthy discussion of Bounty who is identified as the Holy Spirit, and a distinction is made between "bounte wroust" and "bounte unwrouzt," with the latter said to engender the former, such that the soul has free will:

Now hap bounte vnwouzt of his propirte fre wille pat ziuep us also of his bounte fre wille comynge out of his my3t, wipoute eny forwhi, but for ussilf, for to be of his bounte. Now have we wille comynge out of his bounte and out of his my3t, for to be more fre, and he hap wille out of oure my3t of his propre fredom. ${ }^{100}$

The section concludes by reinforcing a distinction between "bounte permanable" and "bounty agreeable." It is again stressed that the latter is engendered in the soul by the former. As pe Myrrour states,

Dis is bounte permanable, pat zildep bi nature of charite pe zifte spredynge of al his bounte, be whiche bounte permanable engendrip bounte agreable, of pe which bounte agreable and of pe which bounte permanable is pe loue amyable of pe loued in soules. ${ }^{101}$

The section is a difficult one in which "bounte agreeable" and "bounte "wrouzt" could, on the one hand, be understood as created grace, a created habitus or supernatural virtue through which the soul is able to love God and achieve deification whilst still retaining her identity as a creature - this would explain how the soul has a free, sinless, will. It could, on the other hand, be read in a Lombardian sense. ${ }^{102}$ Given this, the final annotation seems to be strategically

\footnotetext{
${ }^{97}$ Ibid. 305.6. "these restful usages of pure love" [Kirchberger (n.1 above) 151. 26-27].

${ }^{98}$ Ibid. 305.6 - 7, 9. Kirchberger (n.1 above) notes the first part of this phrase quotes Ps xlv.11 (151, n.1] "Stint ye sometimes and Behold God" [151.28 her emphasis] the second phrase is however, missing from her translation. 'Usage' also appears in annotation 8: "vsage in loues daliaunce" [be Myrrour (n 1 above) 264.11].

${ }^{99}$ Ibid. 329.14 - 18. [Kirchberger (n.1 above) 225.8-15].

${ }^{100}$ Ibid. 334.10-21. [Kirchberger (n.1 above) 238.14-239.11].

${ }^{101}$ Ibid. 334.33 - 36. [Kirchberger (n.1 above) 240.10-16].

102 I am grateful to John Arblaster for this observation. In conjunction with Faesen, Arblaster has argued that the Lombard's position (and so that of the original Mirouer) does not inevitably lead to obliteration without the introduction of a created habitus since love always demands an
} 
placed, just above an initial discussion of bounty. It seems likely that when M.N. writes that the soul's all-its "summe"-is to be found in a knowledge that she derives from God's goodness, he is reminding the reader of a distinction between created and uncreated grace, an idea already implied by his discussion of freedom and inhabitation which he has placed like a thread at key points within his glosses because he interpreted the text in this manner. Indeed, if we revisit this annotation we find M.N. stressing that "Pe summe of pis soule," signifies that "pe Hooli Goost werkip in her [the free soul]" shaping her in relation to "pe goodnesse of God" whence comes all her knowledge. Add to this the stress that we find on inhabitation and the distinction between divine and ordinary habits and we have a position that comes close to that which both Aquinas and Bonaventure espouse. It is perhaps worth noting that, like Marguerite Porete, Aquinas stresses that one who has charity cannot sin because this goes against the nature of charity:

In this respect, no one who possesses charity can sin, in the sense of committing a sin by virtue of that charity; just as no one possessing any form can act contrary to that form by virtue of the form. For example, that which is warm, although it can lose heat and become cold, cannot become cold or be cold by virtue of its warmth. ${ }^{103}$

Although he holds that charity in this life can be lost because we only feel its effects, nonetheless in and of itself true charity always runs contrary to sin. It is not necessarily a sign of ignorance to read Marguerite's text in like manner.

The reading of M.N.'s annotations proposed here however begs the question of how M.N. came into contact with scholastic material on deification. Although we do not know who M.N. was, Watson notes that internal evidence from M.N's prologue indicates that he had some familiarity with "the conventions of 'academic prologue form' at least in "its loose vernacular manifestations," 104 and knew the mystical schema found in Bonaventure's De Triplici Via. ${ }^{105}$ Watson

"other." Despite the importance placed on love, he nonetheless admits the potential for reading this as the soul becoming a fourth person of the godhead but suggests this an unlikely intention of the Lombard, William of St. Thierry or Marguerite: Arblaster and Faesen, "Commune" (n. 10 above).

${ }^{103}$ Aquinas, On Charity (n. 60 above) 99. "et quantum ad hoc, nullus habens caritatem potest peccare, quantum est ex vi ipsius caritatis, sicut neque aliquis habens aliquam formam, ex vi illius formae potest operari contra formam illam; sicut calidum ex vi calidi non potest infrigidare, vel frigidum esse; potest tamen amittere calorem et infrigidari," Quaestio disputata de caritate XII.24.4.

${ }^{104}$ Watson, "Melting" (n. 7 above) 34-35.

105 Ibid. 35, This text appears to have only been held in Carthusian libraries in London, which would, at first glance, suggest a link between M.N. and the Carthusians: Richard Sharpe and James Willoughby, eds, Medieval Libraries of Great Britain (http://mlgb3.bodleian.ox.ac.uk/ 2009-), http://mlgb3.bodleian.ox.ac.uk/authortitle/results/?search type=advanced\&go button_start=Go\& 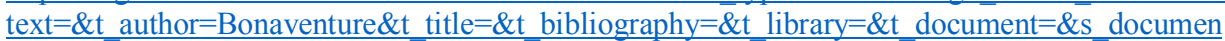 $\mathrm{t}$ type $=\& q$ earliest year $=\& q$ latest year $=\&$ order $b y=$ solr id sort However, the schema that Bonaventure recounts does not originate with him being derived from Pseudo-Dionysius. It appears in works by Hugh and Richard of St. Victor, on whom Bonaventure drew: Paul Rorem, Pseudo-Dionysius (n. 28 above) 219. Hugh and Richard's writings circulated extensively, inside 
also highlights the sophisticated way in which the prologue draws language from the Mirouer together with a host of scriptural allusions and a confident use of French vocabulary which Watson argues is employed with a "self-conscious stylistic." ${ }^{106}$ Roger Lovatt reminds us that an interest in devotional material and an academic background were far from mutually exclusive in this period. In his study of John Blacman's libraries and those of the Carthusians he concludes that "the spiritual elite of the period were also, perhaps to an unexpected degree, an academic elite." 107 These factors potentially support Robert Lerners' proposal that M.N. is Michael Northburgh (d.1361). This has the attraction of bringing the pe Myrrour composition far close to the scholastic discussions of deification in Lombard's Sentences that this essay has been referring to.

However, discussion of union and deification did not cease in the early fourteenth century. We find a number of the English mystics wrestling with the idea in the fifteenth century. ${ }^{108} \mathrm{We}$ also know that there was an interest in vernacular mysticism of a conservative kind both inside and outside of Carthusian circles in this later period. ${ }^{109}$ Gail McMurray Gibson has, for example posited the important Benedictine Abbey of Bury St Edmunds as the possible source for the Middle English play Wisdom, which is replete with borrowings from both Hilton's Scale of Perfection and the Sevene Poyntes of Trewe Love and Everlastynge Wisdame, the Middle English translation of Henri Suso's Horologium Sapientiae. ${ }^{110}$ Bonaventure's Breviloquium and his Commentary on the Sentences were owned by numerous monastic libraries in England in the later Middle Ages. Richard Sharpe and James Willoughby's Medieval Libraries of Great Britain indicates particularly extensive ownership in East Anglia, Cambridge, the East Midlands, Oxford and London between the $14^{\text {th }}$ and $16^{\text {th }}$

and outside Carthusian circles: Sharpe, Medieval Libraries, http://mlgb3.bodleian.ox.ac.uk/authortitle/results/?search type=advanced\&go button_start=Go\& text $=\& \mathrm{t}$ author $=+$ Victor \&t title $=\& \mathrm{t}$ bibliography $=\& \mathrm{t}$ library $=\& \mathrm{t}$ document $=\& \mathrm{~s}$ document typ $\mathrm{e}=\& \mathrm{q}$ earliest year $=\& \mathrm{q}$ latest year $=\&$ order by=solr id sort (accessed 10.06.20). The project builds on Sharpe's earlier work, English Benedictine Libraries: The Shorter Catalogues (London 1996) and Neil R. Kerr's earlier monumental Medieval Libraries of Britain, A List of Surviving Books (London 1941).

106 Watson, "Melting" (n. 7 above) 35.

${ }^{107}$ Lovatt, "Blacman," (n. 24 above) 230.

${ }^{108}$ For recent discussion of Rolle: Albin, Melody (n. 29 above); Nelstrop, On Deification (n. 29 above) esp 148 - 149; Kate Hanch, "Participation in God; Oned by Love: Paul Fiddes in Dialogue with Julian of Norwich," Perspectives in Religious Studies 44.1 (2017) 71-83. Although we lack recent studies of Hilton and the Cloud-Author on deification, the importance of this idea was posited by Edward Vasta, The Spiritual Basis of Piers Plowman (The Hague 1965).

${ }^{109}$ On the role of the Carthusians in translating and circulating vernacular spiritual literature: Suzan Folkerts, "The Transmission and Appropriation of the Vita of Christina Mirabilis in Carthusian Communities," Church Culture and Religious History, 96 (2016) 80-105 esp. 95ff.

${ }^{110}$ Gail McMurray Gibson, The Theater of Devotion: East Anglian Drama and Society in the Late Middle Ages (Chicago 1989). However, none of the relevant abbots of Bury St Edmunds bear the initials M.N: Louis F. Salzman, ed., A History of the County of Cambridge and the Isle of Ely: Volume 2 (London 1948) 199-210. 
centuries. ${ }^{111}$ The same is true of Aquinas' Commentary on the Sentences and Summa Theologiae. Both were widely known Benedictines houses, as well as those of the Brigettines and Augustinian Canons. ${ }^{112}$ That the pe Myrrour is only preserved in Carthusian libraries, should not therefore lead us to discount the possibility that its provenance lies elsewhere. John P.H. Clark has drawn attention to an interest in mystical spirituality amongst Cambridge-based Carmelites in this period, a number of whom had connections to the Cambridge divinity faculty, to which Clark tentatively ascribes a broadly Thomist theology, positing an Cambridge-based East Anglican school running through Ely to Lincolnshire. ${ }^{113}$ Given that Hilton's writing were known in this circle, that like Underhill, Clark suggests in passing that "many of the corrective points made by M.N. are very close to Hilton's teaching in Scale 2,"114 and that a broadly Bonaventurean account of deification has been ascribed to Julian of Norwich, ${ }^{115}$ Clark suggestion of a theologically conservative Cambridge-based East Anglian school extending to Lincolnshire also perhaps warrants further consideration in relation to pe Myrrour's provenance. ${ }^{116}$ Such an exploration is however, beyond the scope of this essay.

\section{CONCLUSION}

\footnotetext{
${ }^{111}$ Sharpe, Monastic Libraries $\quad$ (n. 105 above): http://mlgb3.bodleian.ox.ac.uk/authortitle/results/?search type=advanced\&go button start=Go\& text $=\&$ t author $=$ Bonaventure \&t title $=\& \mathrm{t}$ bibliography $=\& \mathrm{t}$ library $=\& \mathrm{t}$ document $=\& \mathrm{~s}$ documen $\mathrm{t}$ type $=\overline{\& q}$ earliest year $=\& q$ latest year $=\&$ order by $=$ solr id sort (accessed 10.06.20).

112 Sharpe, $\quad$ Monastic Libraries $\quad$ (n. 105 above): http://mlgb3.bodleian.ox.ac.uk/authortitle/results/?search type $=$ advanced\&go button start=Go\& text $=\& \mathrm{t}$ author $=$ Aquinas $\& \mathrm{t}$ title $=\& \mathrm{t}$ bibliography $=\& \mathrm{t}$ library $=\& \mathrm{t}$ document $=\& \mathrm{~s}$ document ty $\mathrm{pe}=\& \mathrm{q}$ earliest year $=\& q$ latest year $=\&$ order by $=$ solr_id_sort $($ accessed 10.06.20).

${ }^{113}$ I am grateful to the anonymous reviewer for drawing my attention to Clark's discussion. For a brief discussion of a Thomist Cambridge school: John P. H. Clark and Rosemary Dorward's introduction to Walter Hilton The Scale of Perfection, trans. idem (New York 1991), esp. 30-33. Hilton's writing were known to the Cambridge Carmelite divine, Thomas Malden, to whom a sentence commentary is ascribed: the Solemn Collations on the Matter of the Sentences. John Stevens, The History of the Antient Abbeys, Monasteries, Hospitals, Cathedrals and Collegiate Churches, Being Two Additional Volumes to Sir William Dugdale's Monasticon Anglicanum (London 1723) vol. II 176. While Stevens provides a list of Carmelite theologians and writings attributed to them, there are limited manuscripts records available for Carmelite theologians in England in this period: Bruce P. Flood Jr., "The Carmelite Friars in Medieval English Universities and Society, 1299-1430," Recherches de théologie ancienne et médiévale 55 (1988) 154-183. None in Steven's list bear the initials M.N.

${ }^{114}$ Clark and Dorward, Scale (n. 113 above) 30.

${ }^{115}$ Nelstrop, On Deification (n. 108 above) esp. 148-149.

${ }^{116}$ For discussion of the conservative stance in English devotional texts: See: Rosalyn Voaden, ed., The Reception of Continental Holy Women in Late Medieval England (Cambridge 1996). For a slightly more positive reading of the theological sophistication of M.N.'s translation: Stauffer, "Yorkshire Circle" (n. 1 above). However, the idea of "Yorkshire Circle" relies heavily on Jonathan Hughes, Pastors and Visionaries: Religion and Life in Late Medieval Yorkshire (Woodbridge 1988) and needs further substantiation. Indeed, Kirchberger detects an East Midlands dialect with some Northernism in pe Myrrour, and posits connections to Hilton (n.1 above) xxxiv.
} 
The purpose of this essay has been to explore possible justifications for viewing M.N.'s annotations as self-consistent, promoting the idea of a created habitus, an idea that resonates with Thomist/Bonaventurean interpretations of deification. Given contemporary scholarship has tended not to read Marguerite's Mirouer through this lens, even if this is the case, some may protest this amounts to a huge diminution of the central message of the Mirouer. Yet we should not forget what a difficult text Marguerite's Mirouer is. Bernard McGinn describes it as "one of the most challenging of the Middle Ages" and scholars continue to disagree about its theological content. ${ }^{117}$ Recently, Wendy Terry has suggested that Marguerite owes a still unappreciated debt to Bonaventure. ${ }^{118}$ Danielle C. Dubois has likewise argued that Marguerite's account of virtue owes more to scholastic discussions than has widely been acknowledged. ${ }^{119}$ What is more, even if we accept that M.N. imposes a fairly conservative Aquinian/Bonaventurean reading of deification on the Mirouer, it is important to remember that this does not necessarily amount to a rejection of deification.

Recent research has significantly refined our picture of Christian understandings of deification. We now know that its earliest orthodox Christian iterations specifically reject the idea of absorption. ${ }^{120}$ Although Jared Ortiz stresses that our understanding of deification in the Latin West is still embryonic, it already seems clear that scholars as diverse as John Cassian and Thomas Aquinas took an interest in and advocated deification, albeit meaning slightly different things by this idea. ${ }^{121}$ It is perhaps time to embrace the idea that thirteenth century presented a varied landscape of deification, in which female mystics like Hadewijch followed William of St Thierry and Peter Lombard, claiming a love union of great immediacy, while scholars, such as Aquinas,

${ }^{117}$ In addition to the scholarship already cited: Bernard McGinn, "Annihilation and Apostolic Teaching in Two Women Mystics: Marguerite Porete (d. 1310) and Madame Jeanne Guyon (d. 1717)," paper read at Madame Guyon (1648-1717). Mysticism and politics at the Court of Versailles, International Colloquium, University of Geneva, November 23rd -24th, 2017. I am grateful to Prof McGinn for sharing this paper with me.

118 Wendy R. Terry, “A Review of the Possible Theological Sources for Marguerite Porete's Mirror," in Companion, ed. Terry and Stauffer (n. 3 above) 59 - 95 at 65-73, who argues for the particular influence of Bonaventure's Soliloquies, although she acknowledges the ideas could come from Augustine. Stauffer argues that M.N. may have altered his translation in line with Bonaventurean ideas that circulated in the Yorkshire Circle: "Yorkshire Circle" (n. 1 above) esp. 179ff. Also on a Bonaventurean model of deification in the North of England: Nelstrop, "The Monk of Farne" (n. 28 above).

119 Danielle C. Dubois, "The Virtuous Fall" (n. 49 above); Idem, "Natural and supernatural virtues in the thirteenth century: the case of Marguerite Porete's Mirror of Simple Souls," Journal of Medieval History 43.2 (2017) 174 - 192. It would be interesting to explore further whether ideas to which Dubois draws attention underpin M.N.'s annotations.

${ }^{120}$ Russell, Deification (n. 67 above).

${ }^{121}$ Jared Ortiz, "Deification in the Latin Fathers," in Called to be Children of God: The Catholic Theology of Human Deification, eds. David Vincent Meconi S.J. and Carl E. Olson (San Francisco 2006) 59-81. On Cassian: Christine Beu, Deification in Cassian's Conferences: Analysis of John Cassian's writings on unceasing prayer in Conferences Nine and Ten as a Description of Deification (Unpublished MA diss., Providence College 2015) http://digitalcommons.providence.edu/theology_graduate theses/8. 
sought to define deification so as to avoid an understanding that could entail absorption. pe Myrrour was translated at the very end of the fourteenth or beginning of the fifteenth century, in the wake of such scholarly discussions. Given that Rolle's texts circulated more widely on the continent than many radical mystical works - and can be read as offering a conservative view of deification-I wonder if it might not be better to think of M.N.'s annotations as part of larger reflections on the nature of deification-a pan-European exploration-in which further research may illustrate that English spirituality plays an not insignificant part.

\section{MANUSCRIPTS CITED}

\section{BIBLIOGRAPHY}

British Library Addition 37790.

Oxford, Bodleian Library, Bodley 505.

St John's College, Cambridge 71.

Pembroke College, Cambridge, 221.

Vatican City, Biblioteca apostolica vaticana, Vat. Lat. 4355.

Vatican City, Biblioteca apostolica vaticana Rossianus 4.

Vatican City, Biblioteca apostolica vaticana Chigianus B IV 14.

Vatican City, Biblioteca apostolica vaticana Chigianus C IV 15.

Vatican City, Biblioteca apostolica vaticana Vat Lat. 3953.

Oxford, Bodleian Library, Laud Latin 46.

\section{PRIMARY SOURCE AND TEXTS}

Aquinas, Thomas, Summa Theologiae, Opera Omnia, Leonine edition (Rome 1895) http://www.corpusthomisticum.org/repedleo.html.

Thomas Aquinas, Scriptum super libros Sententiarum Magistri Petri Lombardi, edited by R.P. Mandonnet. Paris 1929.

Aquinas, Thomas, Quaestio disputata de caritate, in Quaestiones disputatae, $9^{\text {th }}$ revised edition, edited by P. Bazzi et al. Vol. 2. Turin-Rome 1953.

Aquinas, Thomas, On Charity, translated by Lottie H. Kenkzierski. Milwaukee 1984 in The Collected Works of Thomas Aquinas, Electronic Edition. Charlottesville, Virginia, USA: InteLex Corporation.

Aquinas, Thomas, Lectura romana in primum Sententiarum Petri Lombardi, edited by L.E. Boyle and J.F. Boyle, Studies and Texts 125. Turnhout 2006.

Bonaventure, Opera Omnia (Quaracchi) ad clarus aquas. propre florentiam, 18821885.

Bonaventure, Breviloquium, translated by D. V Monte. New York 2005.

Hilton, Walter, The Scale of Perfection, translated by John P. H. Clark and Rosemary Dorward. New York 1991.

Lombard, Peter, Sententiae in IV libris distinctae, edited I. M. Brady. Grottaferrata $1971-81$. 
Lombard, Peter, The Sentences, translated by Giulio Silano. 4 vols. Toronto 2007 2010.

Methley, Richard, Richard Methley, Speculum Animarum Simplicium: A glossed Latin version of "The Mirror of Simple Souls, "edited by John Clark, Analecta Carthusiana 266 (2010).

Porete, Marguerite, The Mirror of Simple Souls, translated by Clare Kirchberger. London 1927.

Porete, Marguerite, "Il Miroir des simples âmes di Margherita Porete," ed. Romano Guarneri, Archivio Italiano per la Storia della Pietà 4 (1965) 501-708.

Porete, Marguerite, The Mirror of Simple Souls: a Middle English Translation, edited by Marilyn Doiron. Rome 1968.

Porete Margaretae [Marguerite], Speculum simplicium animarum, Corpus Christianorum Continuatio Mediaevalis 69, edited by Paul Verdeyen. Turnholt 1986.

Porette, Margeret [Porete, Marguerite], The Mirror of Simple Souls, foreword Kent Emery, translated by Edmund Colledge, Jack C. Marler and Judith Grant, Notre Dame Texts in Medieval Culture 6. Notre Dame 1999.

Rolle, Richard, Richard Rolle's Melody of Love: A Study and Translation with Manuscript and Musical Contexts, edited and introduction by Albin, Andrew. Toronto, 2018.

\section{SECONDARY SOURCES}

Arblaster, John, "The Pious Jackal and the Pseudo-Woman: Doctrines of Deification in Medieval France," in Mysticism in the French Tradition: Eruptions from France, edited by Louise Nelstrop and Bradley B. Onishi, 12148 (Farnham, 2015).

, "On Becoming 'not God but what God is:' Essays on the Doctrine of Deification in the Late Medieval Low Countries". Unpublished PhD diss., KU Leuven 2016.

Arblaster, John and Rob Faesen, "“Commune à tous par largesse de pure charité': Common Love in Beatrice of Nazareth and Marguerite Porete," Ons Geestlijk Erf, 84.4 (2012) 297-323.

Beu, Christine, Deification in Cassian's Conferences: Analysis of John Cassian's writings on unceasing prayer in Conferences Nine and Ten as a Description of Deification. Unpublished MA diss., Providence College 2015. http://digitalcommons.providence.edu/theology graduate theses/8.

Carruthers, Mary, "Sweetness," Speculum 81.4 (2006) 999-1013.

Colledge, Edmund and Romana Guarnieri, "The glosses by M. N. and Richard Methley to 'The Mirror of Simple Souls," ' in The mirror ed., Doiron (n. 1 above), Appendix, 357-382 at 371.

Cré, Marlene Vernacular Mysticism in the Charterhouse: A Study of London, British Library, MS Additional 37790. Turnhout 2006.

, "The Mirror of Simples Souls in Middle English Revisited: The translator and the compiler," in Marguerite Porete, edited by Sean L., Field, 
Robert E. Lerner and Sylvain Piron, Marguerite Porete et le Miroir des simples ames: perspectives historiques, philosophiques et littéraires, 249-262. Paris 2013.

, "Further Thoughts on M.N.'s Middle English Translation of Marguerite's Mirouer des simples âmes anienties," in Companion to Marguerite Porete and The Mirror of Simple Souls, edited by Wendy R. Terry and Robert Stauffer, 240-263. Leiden 2017.

Doiron, Marilyn, "The Middle English Translation of The Mirouer of Simples Ames," in L. Reypens and Albert Ampe, Dr L. Reypens-Album (Antwerp 1964) $131-152$.

Dubois, Danielle C., "The Virtuous Fall: Marguerite Porete, Meister Eckhart and the Medieval Ethics of Sin," Journal of Religious Ethics 3.3 (2015) 432-453. ., "Natural and supernatural virtues in the thirteenth century: the case of Marguerite Porete's Mirror of Simple Souls," Journal of Medieval History 43.2 (2017) 174-192.

Falvay, Dávid, "Medieval and Modern Readership of Marguerite Porete's Mirouer des simples ames anienties: The Manuscripts of the continental Latin and Italian Traditions," in In principio fuit interpres: The Medieval Translator/Traduire au Moyen Âge 15, edited by Alessandra Petrina, 85-96 Turnhout 2013.

"The Italian Version of The Mirror: Manuscripts, Diffusion and Communities in the $14^{\text {th }}$ and $15^{\text {th }}$ Centuries," in Companion to Marguerite Porete and The Mirror of Simple Souls, edited by Wendy R. Terry and Robert Stauffer, 218-239. Leiden 2017.

Field, Sean L. The Beguine, the Angel, and the Inquisitor: the Trials of Marguerite Porete and Guiard of Cressonessart. Notre Dame 2012.

Field, Sean L., Robert E. Lerner and Sylvain Piron, eds., Marguerite Porete et le Miroir des simples âmes: perspectives historiques, philosophiques et littéraires. Paris 2013.

, "A Return to the Evidence for

Marguerite Porete's authorship of the Mirror of Simple Souls," Journal of Medieval History 43.2 (2017) 153-173.

Finke, Laurie A., “'More Than I Fynde Wirtten,' Dialogue and Power in the English Translation of The Mirror of Simple Souls," in Performance and Transformation: New Approaches to Late Medieval Spirituality edited by Mary A. Suydam and Joanne E. Ziegler, 47-67 London, 1999.

Flood Jr., Bruce P., "The Carmelite Friars in Medieval English Universities and Society, 1299-1430," Recherches de théologie ancienne et médiévale 55 (1988) $154-183$.

Folkerts, Suzan "The Transmission and Appropriation of the Vita of Christina Mirabilis in Carthusian Communities," Church Culture and Religious History, 96 (2016), 80-105.

Friedman, Russell L., "The Sentences Commentary, 1250-1320. General Trends, The Impact of Religious Orders, and the Test Case of Predestination," in Mediaeval Commentaries on the Sentences of Peter Lombard: Current Research. Vol. 1, edited by Gillian R. Evans, 41-128. Leiden 2001. 
Hanch, Kate, "Participation in God; Oned by Love: Paul Fiddes in Dialogue with Julian of Norwich," Perspectives in Religious Studies 44.1 (2017) 71-83.

Hasenohr, Geneviève, "The Tradition of the Mirror of Simple Souls in the Fifteenth Century: From Marguerite Porete (d. 1310) to Marguerite of Navarre," translated by Zan Kocher, in Companion to Marguerite Porete and The Mirror of Simple Souls, edited by Wendy R. Terry and Robert Stauffer, 155-185. Leiden 2017.

Hughes, Jonathan, Pastors and Visionaries: Religion and Life in Late Medieval Yorkshire. Woodbridge 1988.

Humbert-Thomas Conus "Divinisation: B. Théologiens du $13^{\mathrm{e}}$ siècle," Dictionnaire de Spiritualité. Paris 1954

Gibson, Gail McMurray, The Theater of Devotion: East Anglian Drama and Society in the Late Middle Ages. Chicago 1989.

Juilfs, Jonathan, "Mirrors on the Wall: Which One Is Fairest of Them All?" in Companion to Marguerite Porete and The Mirror of Simple Souls, edited by Wendy R. Terry and Robert Stauffer, 323-338. Leiden 2017.

Kerby-Fulton, Katherine, Books Under Suspicion: Censorship and Tolerance of Revelatory Writing in Late Medieval England. Notre Dame 2006)

Kerr, Neil R., Medieval Libraries of Britain, A List of Surviving Books. London 1941.

Kocher, Zan, "The Apothecary's Mirror of Simple Souls: Circulation and Reception of Marguerite Porete's Book in Fifteenth-Century France," Modern Philology, 111.1 (2013) 23-47.

Lovatt, Roger, "The Library of John Blacman and Contemporary Carthusian Spirituality," Journal of Ecclesiastical History 43.2 (1992) 195-230.

Lerner, Robert E., The Heresy of the Free Spirit in the Later Middle Ages. Los Angeles 1976.

, "The Image of Mixed Liquids in Late Medieval Thought," Church History 40 (1971) 397-411. (2010) 91-116.

"New Light on 'The Mirror of Simple Souls'," Speculum, 85.1

Livesey, Steven J., "Lombardus electronicus: A Biographical Database of Medieval Commentators on Peter Lombard's Sentences," in Mediaeval Commentaries on the Sentences of Peter Lombard: Current Research. Vol. 1, edited by Gillian R. Evans, 1-23. Leiden 2001.

Long, R. James, "The Beginning of a Tradition: The Sentences Commentary of Richard Fishacre OP," in Mediaeval Commentaries on the Sentences of Peter Lombard: Current Research. Vol. 1, edited by Gillian R. Evans, 345-357. Leiden 2001.

McGinn, Bernard, “Annihilation and Apostolic Teaching in Two Women Mystics: Marguerite Porete (d. 1310) and Madame Jeanne Guyon (d. 1717)," paper read at Madame Guyon (1648-1717). Mysticism and politics at the Court of Versailles, International Colloquium, University of Geneva, November 23rd24th, 2017. 
Marin, Juan, "Annihilation and Deification in Beguine Theology and Marguerite Porete's Mirror of Simple Souls," Harvard Theological Review, 103:1 (2010) 89-109.

Middle English Dictionary: https:/quod.lib.umich.edu/m/middle-englishdictionary/dictionary.

Muraro, Louisa, "Le mirouer des simples ames de Marguerite porete: Les avatars d'un titre," Ons geestelijk erf 70 (1996) 3-9.

Nelstrop, Louise, "The Monk of Farne: A Forgotten Medieval English Mystic," in Mystical Doctrines of Deification: Case Studies in the Christian Tradition edited by John Arblaster and Rob Faesen, 135-151. London 2018. , On Deification and Sacred Eloquence: Richard Rolle and Julian of Norwich. Abingdon 2020.

Newman, Barbara, From Virile Woman to WomanChrist: Studies in Medieval Religion and Literature. Philadelphia 1995.

Ortiz, Jared, "Deification in the Latin Fathers," in Called to be Children of God: The Catholic Theology of Human Deification, edited by David Vincent Meconi S.J. and Carl E. Olson, 59-81. San Francisco 2006.

Renevey, Denis, "Le Pouvoir de la Voix Masculine: Le Case de la Version en Moyen-Anglais du Mirror des Simples Ames de Marguerite Porete," in Body Politics; Discours Corporels \& Corps Discursifs, Special Edition of Études de Lettres: Revue de la Faculté de l'Université de Lausanne 258, edited by Lucy Perry, Kirsten Stirling and Boris Vejdovsky (2001) 33-54.

Rorem, Paul, Biblical and Liturgical Symbols within the Pseudo-Dionysian Synthesis. Toronto 1984.

, Pseudo-Dionysius: A Commentary on the Texts and an Introduction to their Influence. New York 1993.

Roseman, P.W., "Fraterna dilectio est Deus: Peter Lombard's Thesis on Charity as the Holy Spirit," in Amor amicitiae: On the Love that is Friendship: Essays in Medieval Thought and Beyond in Honor of the Rev. Professor James McEvoy," edited by T.A.F. Kelly and P.W. Roseman, 409-436. Peeters 2004.

Russell, Norman, The Doctrine of Deification in the Greek Patristic Tradition. Oxford 2004.

Salzman, Louis F., ed., A History of the County of Cambridge and the Isle of Ely: Volume 2. London 1948.

Sargent, Michael G., "The Transmission by the English Carthusians of some Late Medieval Spiritual Writing," Journal of Ecclesiastical History 27 (1976) 225240.

$253-79$.

"The Annihilation of Marguerite Porete," Viator 28 (1997)

"'Le Mirouer des simple âmes' and the English Mystical

Tradition," in Abendländische Mystik im Mittlealter: Symposino Kloster Engelberg 1984, edited by Kurt Ruh, 423-465. Stuttgart 1986.

"Marguerite Porete," in Medieval Holy Women in the

Christian Tradition c.1100-c.1500, edited by Alastair Minnis and Rosalyn Voaden, 291-303. Turnhout 2010. 
, "Medieval and Modern Readership of Marguerite Porete's Mirouer des simples ames anienties: The French and English Traditions," in Middle English Religious Writing in Practice: Texts, Readers, and Transformations, ed. Nicole R. Rice, 47-89. Turnhout 2013.

Sharpe Richard and James Willoughby, eds., Medieval Libraries of Great Britain (http://mlgb3.bodleian.ox.ac.uk/2009-).

Sharpe, Richard, English Benedictine Libraries: The Shorter Catalogues. London 1996.

Stabler Miller, Tanya, The Beguines of Medieval Paris: Gender, Patronage, and Spiritual Authority. Philadelphia 2014.

Stauffer, Robert F., "M.N. and the Yorkshire Circle: The Motivation Behind the Translation of the Mirouer des Simples Ames in Fourteenth - Century England". Unpublished PhD diss., Arizona State University 2011.

, "Possibilities for the Identity of the English Translator of the

Mirror of Simple Souls," in Companion to Marguerite Porete and The Mirror of Simple Souls, edited by Wendy R. Terry and Robert Stauffer, 264-289. Leiden 2017.

Stevens, John, The History of the Antient Abbeys, Monasteries, Hospitals, Cathedrals and Collegiate Churches, Being Two Additional Volumes to Sir William Dugdale's Monasticon Anglicanum. Vol II London 1723.

Terry, Wendy R., "A Review of the Possible Theological Sources for Marguerite Porete's Mirror," in Companion to Marguerite Porete and The Mirror of Simple Souls, edited by Wendy R. Terry and Robert Stauffer, 59-95. Leiden 2017

Townsend, Luke Davis, "Deification in Aquinas: A Supplementum to The Ground of Union," Journal of Theological Studies N.S. 66.1 (2015) 204-234.

Trombley, Justine L., "The Latin Manuscripts of The Mirror of Simple Souls," in Companion to Marguerite Porete and The Mirror of Simple Souls, edited by Wendy R. Terry and Robert Stauffer, 186-217. Leiden 2017.

, "New Frontiers in the Late Medieval Reception of a Heretical Text: The Implications of Two New Latin Copies of Marguerite Porete's Mirror of Simple Souls," in Late Medieval Heresy: New Perspectives: Essays in Honor of Robert E. Lerner, edited by Michael D. Bailey and Sean L. Field, 157-177. York 2018.

Turner, Denys, The Darkness of God: Negativity in Christian Mysticism. Cambridge 1995.

Underhill, Evelyn, The Essentials of Mysticism and Other Essays. London 1920. $345-54$. , Evelyn, "The Mirror of Simple Souls," Fortnightly Review 95 (1911)

Vasta, Edward, The Spiritual Basis of Piers Plowman. The Hague 1965.

Voaden, Rosalyn, ed., The Reception of Continental Holy Women in Late Medieval England. Cambridge 1996.

Watson, Nicholas, Richard Rolle and the Invention of Authority. Cambridge, 1991. , Nicholas “"Melting into God the English Way': Deification in the Middle English Version of Marguerite Porete's Mirour des simples âmes anienties," in 
The Reception of Continental Holy Women in Late Medieval England, ed. Rosalyn Voaden, 19-50. Cambridge 1996.

Zuijdwegt, Geetjan, “'Utrum caritas sit aliquid creatur in anima:' Aquinas on the Lombard's identification of charity with the Holy Spirit," Recherches de Théologie et Philosophie médiévales 79.1 (2012) 39-74. 